\title{
Language mechanisms of building the ironic text and ways of their linguistic research (linguistic pragmatic aspect)
}

\author{
Tatyana Chernyshova \\ Altay State University, Russia \\ labrlexis@gmail.com
}

\begin{abstract}
The article is devoted to the study of means and ways of modelling the comic effect in contemporary ironic media texts as well as to characterizing the method of their linguistic description in the linguistic pragmatic aspect. Special attention is paid to the ways of linguistic analysis of the conflict in ironic media text, which is the object of a court case.

Within the complex linguistic analysis, including the semantic analysis to reveal the "semantic aspects," and on the material of the editions Kommersant and Moskovsky Komsomolets, the authors described the signals of irony as language play and as a socially marked way of communication, defining their stylistic variety. On the example of ironic media text which is the object of a court case, it is established that the basic way to model the comic (ironic) subtext in contemporary media texts is the contrast used both at textual and subtextual levels. The article draws the conclusion that the comic form of presentation of the ironic text content cannot be the object of a court case because it is connected with the evaluation and expression of the author's own opinion.
\end{abstract}

Keywords: humour, irony, media text, signals of irony, comic effect.

\section{Introduction}

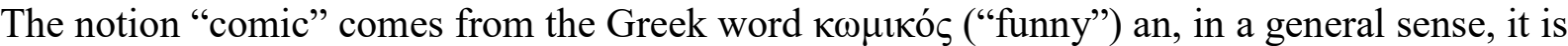
defined as "the category of aesthetics characterizing funny, simple, awkward or nasty sides of the reality and spiritual life" (Novaya filosofskaya entsiklopediya 2020).

In spite of clear interest of scholars in the phenomenon of the comic which is reflected in many interpretations of the phenomenon (see: Dziemidok 1974; Raskin 1985; Weinrich 1987; Sychev 2003; Weinrich 2012; Ermida \& Chovanec 2012; Tsami 2012; Shilikhina 2014), the language of humour has not been studied well until the 20th century (Ermida \& Chovanec 2012: 1-8). But since the 20th century and so far, there has been a constant interest of scholars in the types and genres of comic, special means of its expression, functions, and ways to achieve the comic effect. 
One of the types of the comic, connected with the meaning play and presented in a variety of forms, types, and functions, is irony.

The problems of irony studies are described in a number of studies, among which there are the book About the comic by Dziemidok (1974), the article The Linguistics of Lying by Weinrich (1987: 2012), the research Irony as relevant inappropriateness by Attardo, the PhD dissertation The discursive practice of irony: cognitive, semantic, pragmatic aspects by Shilikhina (2014), etc.

One of the problems solved by scholars nowadays is the definition of the irony status in comparison with humour and satire. Thus, a Polish researcher Dziemidok in his book About the comic (Dziemidok 1974: 98-105) suggests choosing "the attitude of an artist to the objects of the comic" as the most important criterion for the classification of the complex comic ("humorously satiric, rational and evaluative"):

The humorous position is inactive and nonaggressive... Humor considers life imperfection and human weaknesses as something we have to reconcile with, which deserves indulgence. The satiric position, in its turn, always means the constant and uncompromising struggle against evil, the condescension and tolerance of a humorist are not characteristic of satirist.

(Dziemidok 1974: 99)

The closeness of irony and satire, as Dziemidok thinks, after the researcher Collins-Suobi, is conditioned by two moments:

(...) first of all, they express disapproval and critique in opposition to humour, and secondly, differing from the comic in its narrow sense of the word they both - as well as humour - have the intellectual character and brightly expressed emotional colour (...)

(Dziemidok 1974: 101)

The opinion of Konkov is close to the described interpretation of the irony status: in the scholar's opinion, irony is "a type of relations, meaning the critical attitude to the reality and based on the intellectual effort" (Duskaeva 2018: 252). Satire is defined as the way of "critical analysis of the reality," expressing "a complete denial of social sins, intolerant attitude towards them" (Duskaeva 2018: 253).

But the complexity of the irony mechanism denies the distinct typological opposition. Y. Propp, for example, suggests another foundation for systematization of the comic types: "The material shows that the most efficient way is to set the reasons for laughter. Simply saying, it is necessary to understand what people laugh at, what they think is funny. In other words, the material must systematize the objects of laughter" (Propp 1999). As a result, the scholar describes three types of the comic fulfilled through "laughter," "mockery," and "mocking humour": "It is enough, for example, to point out that the vastest area of satire is based on the mocking laughter" (Propp 1999).

Almost complete similarity of irony and satire is presented in the work by Popova, describing the means of irony creation in satiric, political, creolized text (Popova 2017: 7-17). Shilikhina, studying irony in different research fields - philosophical, aesthetic, post-modernist, literary, linguistic, and pragmatic - draws the conclusion that the margins of the notion "irony" and its status in relation to other types of the comic are still the subject to discussion (Shilikhina 2014: 79).

The pieces of research by Weinrich $(1987,2012)$, Volkov (1995), Attardo (2000), Chepkina (2000), Moskvin (2006), Klushina (2008), Shilikhina (2014), and others formulate basic approaches to the study and understanding of irony fulfilled in ironic texts, ironic jokes which appeared in the world in ancient times and went a long way until now, undergoing a long 
modification from "more or less disgraceful dissimulation, indeed a reductive" (Weinrich 2012: 76), as it was percept by ancient Greeks, to the understanding if irony's role as "midwifery which does not distribute truth but wants it to be discovered. (...) After the ironic destruction of some false and conceited opinion comes the construction of clear concepts and true knowledge" (Weinrich 2012: 76).

As the brief review of literature devoted to the study of irony has shown, it has been studied mostly on the materials of fictional texts for many years. At the beginning of the 21 st century, the study on irony included new material - texts of academic, political, and common discourse, and computer-intermediated communication (Shilikhina 2014: 250-285).

The important social function of political humour is described in the works by Tsakona and Popa, who underline the fact that political discourse owns its popularity to mass media. Though it seems "unserious" and "not essential," in reality, "(...) humour constitutes a form of permitted disrespect (...), seems to heighten our own sense of freedom in the way we express ourselves (...)" (Tsakona \& Popa 2013: 6). Utterances in the comic form have a purpose of serious intentions and reflect a certain position towards real people and real situations (Tsakona \& Popa 2011: 9-16).

The problems of creating an ironic media text as a type of political discourse are set and solved in the studies by Chepkina (2000), Lazareva (2005), Klushina (2008), Tsakona and Popa (2011, 2013), Chovanec and Ermida (2012); Raskin (2012), Shilikhina (2014), Chernyshova (2014), Popova (2017), Konkov (2018), and others. In the book review devoted to the appearance of the magazine Language and Humour in the Media (2012), Tsami draws readers' attention to the important issue of the contemporary study of media texts in the aspect of humour, presented in the collection of reviews. In the author's opinion, "The major strength of the present collected volume is that it brings together various studies on humour coming from the fields of discourse analysis, communication studies, sociolinguistics, pragmatics, computational linguistics, intercultural and translation studies, and rhetoric" (Tsami 2012: 96-97).

The important and little studied aspect of ironic media text studies is the possibility to study its linguistic-pragmatic potential fulfilled in real processes of communication: the features of the ironic media text that determine its conflict potential have not been studied, the status of such texts and the means and methods of their linguistic analysis are not defined.

The abovementioned aspects are conditioned by the features of political humour, mentioned by Tsakona and Popa, common, in our opinion, for ironic political media texts: such humour in texts is used to present the political reality; political humour is critical and creative; behind the humorous content of the statements of politicians and citizens lies the desire to convey new ideas and creatively solve political (Tsakona \& Popa 2011: 6-7).

Some scholars point out the image forming and discrediting potential of ironic media texts. Lazareva formulates an interesting viewpoint on the nature of the influencing force of ironic texts, which must not be underestimated:

(...) it [irony] makes the critique sharper and more efficient, often making a reader forget about the real meaning of the events and follow the author's will. In contemporary political struggle with mass media involved, the irony becomes a serious weapon and its deliberate use in journalistic texts leads to the formation of a certain image of a person or an event.

(Lazareva 2005: 3)

Such an interpretation of irony is shared by Moskvin. Analyzing the works by Zhukova, Harris, and Chepkina (see: Moskvin 2006: 121-122), the scholar claims that irony is the "discrepancy of the expressed and the meant, the vision and the meaning" (Moskvin 2006: 122). Being pretence, it has the purpose of discrediting the object through "indirect critique." So "the sphere 
of the ironic action is limited to some ethic taboos, and its violation turns a healthy ironic scepsis into "ironic cynicism" (Moskvin 2006: 122).

Chepkina also makes her contribution to the discussion of the discrediting potential of ironic media texts. She believes that though with the spread of ironic cynicism there are many critical voices addressing contemporary journalism, "irony, as a textual code, way of transmitting and perceiving information does not deserve accusations. (...) Irony is able to soften the speech aggression, widely spread nowadays, including political and journalistic texts" (Chepkina 2000: 221).

Belchikov, Gorbanevsky, Zharkov - the authors of the collection of works Methodic recommendations to the questions of linguistic expertise of arguable mass media texts (2010) agree with the scholar. The experts claim that ironic media texts have no discrediting effect: "(...) irony cannot be the object of court case, as it is connected with perception; one and the same ironic utterance is perceived differently by different people: a positive, kind irony for one and a negative, evil for another, and some of them may not see the ironic colour" (Belchikov, Gorbanevsky, Zharkov 2010: 138).

Nevertheless, ironic media texts of critically evaluating nature are sometimes considered conflicting and subject to the Russian civil courts. This circumstance testifies to the necessity to study such texts and develop methods of their linguistic research, relevant to their linguistic pragmatic content (Duskayeva 2019).

\section{Method and process}

The object of our consideration in the article is ironic media texts, the subject is the means and ways of modelling the comic effect in ironic texts and methods of their linguistic description in the linguistic pragmatic aspect - in this case, we are interested in the possibility of conducting linguistic analysis of an ironic media text as an object of a court case (Chernyshova \& Klink 2019; Medialingvistika 2019).

The purpose of the research is: 1) to study the means and ways of modelling the comic effect in contemporary ironic media texts; 2) to describe and test the methods of linguistic analysis of conflict texts with ironic content through linguistic pragmatics.

The study is conducted within the complex linguistic-pragmatic approach. Ironic texts were subject to complex stylistic analysis of the text and language units, which also implied the means of semantic analysis to completely and deeply understand utterances (see Odintsov 2007; Chernyshova 2009: 147-153); interpretive analysis of text, text compression and paraphrasing techniques (Murzin \& Stern 1991; Demyankov 2003) - these procedures analysed the logic of the author's reasoning and intention of the author of the text; lexical-semantic analysis techniques have been used to study the contextual meaning of linguistic units in spoken words and their stylistic function (Kozhina 2014; 1987); the stylistic and genre features of the utterances and the standard features of their functioning in society were studied on the basis of the methods of discursive-pragmatic analysis of the text (Kozhina 2014; Shmeleva 2007).

To uncover the second (ironic) textual level, we used semantic analysis, meant to reveal the interdependent and mutually conditioned "semantic aspects" (Myrkin 1994).

\subsection{Material}

While selecting the material, we considered the general stylistic direction of editions, focus on a certain audience, the presence of the ironic content in publications. The research is conducted 
on the material of contemporary Russian printed press: the newspapers Kommersant ${ }^{1}$ and Moskovsky Komsomolets ${ }^{2}$ from 2001-2020. The newspaper Kommersant has a traditional reputation of a "quality" business edition, which is characterized with solid social political and economic information. Its print run is over 100 thousand copies; the semiannual audience in Russia, according to Mediascope. NRS-Russia is over 4 million; people with a higher education are $65 \%$ of the audience, $60 \%$ of which are top managers and specialists ${ }^{3}$. The newspaper Moskovsky Komsomolets ${ }^{4}$ specializes in publications of sharp social and political materials, economic reviews, urban news, secular chronicles, and entertaining information ${ }^{5}$ and aims at a large audience. The print run of the edition is 700000 copies; the audience of one issue is over 1000 000. Social features of the audience: gender share - 45\% (males) and 55\% (females); age $-45 / 65+$. The linguistic analysis of the ironic text, which became the object of the court case in 2013, is conducted on the material of the publication in the advertising informational magazine Leader (Iskitim, Russia ${ }^{6}$ ).

\section{Means and ways of modelling the comic effect in ironic texts}

\subsection{Peculiarities of forming the mechanisms of irony in contemporary media}

The critical reconsideration of reality in contemporary Russian media texts is fulfilled through the category of social evaluation which often leads to the fact that authors apply various means of irony creation in media texts (Chernyshova 2014) - from frequent ironic jokes, which fill neutral texts, to a socially coloured media text, filled with ironic style from the beginning to the end. The review of relevant scientific literature, described in the beginning, let us distinguish the most important aspects of forming the mechanisms of irony, topical for the study of contemporary media texts:

- "irony is a discursive practice - a regular way to say something, which is common for a certain language society" (Shilikhina 2014: 12); as a discursive phenomenon, irony "appears in the process of communication as a result of mutual actions of the speaker and the listener" (Shilikhina 2014: 80);

- irony is often characterized as "one of the ways of a parable, when the subject or its feature is defined with a word or words of a directly opposite meaning to comically characterize the real meaning of the subject" (Volkov 1995); as "significant inadequacy", which inevitably draws the reader's attention (Attardo 2007);

- the meaning of ironic utterances is bivalent: it carries the direct meaning and indirect meaning simultaneously, and "the correlation of these two semantic aspects (inadequacy, to be exact) bears the hidden denial" (Attardo 2007; Shilikhina 2014: 70);

- different levels of the ironic text are meant for different readers: "The first level may be considered for simple people, who understand the speech work unambiguously. And it is the second level of perception which contains the irony" (Klushina 2008: 198-199);

- "the process of understanding the irony includes two steps: the addressee must understand the direct meaning of the utterance, then correlate it with the context and, finding

\footnotetext{
${ }^{1}$ https://www.kommersant.ru/

${ }^{2}$ https://www.mk.ru/daily/newspaper/

${ }^{3}$ https://www.kommersant.ru/about/kommersant

${ }^{4}$ https://www.mk.ru/press-center/

${ }^{5}$ https://ria.ru/20091211/198562973.html

${ }^{6} \mathrm{http}: / /$ nvb.ru/firmy-novosibirska/lider_20.html
} 
the discrepancy on the pragmatic level, pass to the next step - the search of hidden meanings" (Attardo 2001; Shilikhina 2014: 70);

- understanding of irony is connected with understanding the author's intention and worldview: the peculiarity of the author's communicative task in the ironic text is to hide true feelings of the author under the "mask" of exclusively positive evaluation of actions and behavior of people who are mentioned in the text (Moskvin 2006: 121);

- two main functions of irony are traditionally distinguished: irony as a language play aims at creating the joking tone of the text; 2) irony as "a socially marked way of communication, setting the special type of relations between the participants of communication" (Shilikhina 2014: 99) means interpretation of the events described through the category of social evaluation (Klushina 2008: 1994);

- irony in texts is accompanied with various types of "irony signals": in Weinrich's opinion, in printed text, it may be "a cluster of high sounding utterances, risky metaphors, too long phrases, word repetition or $-(\ldots)$ italics and quotation marks (...). In most cases (...) these are language signals: words, sounds and prosodic peculiarities" (Weinrich 1987); about the language means of ironic expression also see (Lazareva 2005; Shilikhina 2014).

- Discussing the function of irony usage in texts of various genres - from fiction to colloquial - the scholars mark their variety: irony may serve as a stylistic means of creating the comic image; it may also be a semantic foundation of the text (Volkov 1995; Klushina 2008).

Irony, in both functions, is used to transmit the author's ironic model of reality from the author to the reader. That is why the pragmatic aspect of the ironic code in contemporary media texts becomes so topical, though not predictable sometimes.

\subsection{Irony signals in contemporary media text}

The comic effect in ironic utterances is actualized due to the figurative meaning, based the semantic opposition - the contrast which excludes the possibility of literate understanding of the utterance. These definitions of irony imply the peculiarity of the author's communicative task for the ironic text - to hide true feelings of the author under the "mask" of exclusively positive evaluation of actions and behavior of people, who are described in the text. Not accidentally, irony is translated as "pretence" in Greek (Moskvin 2006: 121). Based on the mentioned signs of irony, we shall illustrate some irony signals in contemporary media texts on the example of publications from two editions of different years (2001-2020): Moskovsky Komsomolets $^{7}$ and Kommersant ${ }^{8}$.

1) Irony as language play, aimed at creating the joking tone of a neutral text, is often used in the Kommersant headlines. This feature of phatic journalism is noticed by Chepkina, who claims that irony "often sticks to the headline, which incorporates the text in the general stylistics of the edition, while the content itself is quite serious" (Chepkina 2000: 223). While creating the headlines for the newspaper Kommersant publications, the ironic style of which has not changed for the last 20 years (2001-2020) (Chernyshova 2009:118), the irony signals may be:

- " "a colloquial word, for example, loom - compare: "Loom - colloquial. To be foreseen, expected" (Dictionaries and encyclopedias on the Academic, 2020a): "Apartments loomed

\footnotetext{
${ }^{7}$ https://www.mk.ru/daily/newspaper

${ }^{8} \mathrm{https}: / / \mathrm{www} . \mathrm{mk} \cdot \mathrm{ru} / \mathrm{daily/newspaper}$
} 
to those in the queue" (about the governmental support of the project owners in Moscow, 23 April 2020);

- a colloquial set phrase: "French suburbs played with fire" (about sharp social contradictions in the suburbs of Toulouse, Stratford and Paris under quarantine 23 April 2020) - compare: "Play with fire: a colloquial variant of the set expression joke with fire to risk imprudently" (Dictionaries and encyclopedias on the Academic, 2020b);

- language play: "Bank quaranties" (the article is devoted to the meeting of Russian bankers with the President, 23 April 2020) - the word "quaranties" is a contamination of two language units: guaranty and quarantine, which result in an occasional word to aim at the comic effect creation;

- the use of textual allusions, implying a precedent text - a certain well-known fiction or non-fiction work (Moskvin 2006: 321), for example: "a rare passenger flies to America" (the publication is devoted to the tragedy of 11 September 2001 in America, 11 September 2001): the headline is founded of the paraphrase of the famous quotation from N.V. Gogol's "Evenings in the village near Dikanka": A rare bird flies to the middle of the Dnepr! etc.

In the newspaper Moskovsky Komsomolets, ironic headlines are often built on the combination of several means of irony creation, for example the headline "Food for needy, those who disagree are through the hoop" (about the price rise of food during the epidemic, 25 April 2020), the publication headline includes a shortened colloquial expressive phraseological unit "put through the hoop" ("Colloquial. Expressive. To aggressively stop any evil actions, behavior, intentions") (Dictionaries and encyclopedias on the Academic, 2020c) and the whole headline points at the byword from a Russian film "Brilliant Arm" ("Ice cream for children, flowers for female") etc.

Such a way to create irony is the business card of the edition - this feature is well illustrated with texts devoted to the 2004 win of the independent candidate (the popular ex-actor Michael Evdokimov) for the position of the Altay region governor (Chernyshova 2009: 235-236). The acid-ironic evaluation of the new governor is found in the article under the headline "The 'redsnouted' chief" (Moskovsky Komsomolets, 6-13 April 2004). The headline plays with two precedent texts: the title of O. Henry's story The Ransom of Red Chief and the set expression "red mug" from a popular humorous story by Evdokimov, written in the beginning of 2000s, about a man coming from the Russian sauna with a "red mug". The change of colloquial and tabooed (but common for readers/viewers) word "mug" with colloquial and rude (but "strange" in a wide context) word "snout" destroys the common image of the utterance and colors the headline with acid ironic tones. But the content of the publication, positively characterizing the winner, allows evaluating such headlines as a stylistic peculiarity of the edition, meant for "its reader and aiming at the achievement of a fast rhetoric effect (Chernyshova 2009: 235-236).

2) The combination of irony as a language play, aimed at creating the joking tone in the text, and irony as a socially marked way of communication is also presented in contemporary Russian media texts. The purpose of such texts is to express the author's attitude to the most important contemporary problems through ironic signals. In Chepkina's opinion, 'inevitable ambiguity of irony creates the communicative 'noise,' ambiguous understanding which is valuable for the addressee because in this case he identifies not with a person or a speech subject, but with the discourse itself" (Chepkina 2000: 224). We shall illustrate irony signals and ways to create the comic with the material of the newspaper Kommersant publications, the ironic tone of which is supported with the desire not only to make the reader laugh, but also to make him find hidden senses (Attardo 2001). Thus, we may speak that the ironic style in this edition is a common discursive practice (Shilikhina 2014: 12), a regular means of dialogue with the reader. 
We shall show irony signals on the example of a headline complex of the article "Watch the roots" (Kommersant, 22 April 2014). By headline complex we mean the structural semantic combination of elements, semantically and conceptually connected with the main massive of the text: these are the headline, subhead, leads, photo comments, and other elements.

The headline of the article under analysis is "Watch the roots" (1), the subhead is "The State Council (that is, the State Council of the Russian Federation, the chairman of which is the Russian President ${ }^{9}$ ); it discussed the rural life and the ways from the plough to the Russian authorities" (2), depicting the meeting of the State Council. The text, devoted to the problems of agriculture, is written in an ironic style and is completely filled with ironic subtexts. In the formation of the comic effect, the photo comment is also important because we may see the members of the State Council of the Russian Federation who took part in the meeting: "Participants of the State Council understood that they had to reconnect not only to the Russian President Vladimir Putin (when he would appear), but also to their ground and to their roots (which are yet to be found)" (3).

The irony signal in this text is the language play, destroying the common image of the speech set expressions and creating the mocking tone. The language play is founded on the clash of contemporary and old meanings of the words used.

(1) The comic tone is within the headline of the publication - "Watch the roots", which contains the set expression "watch the root," including the obsolete bookish verb watch, used in the meaning "to see, to look" (Dictionaries and encyclopedias on the Academic, 2020d). In contemporary Russian, the phraseological unit "watch the root" means: "To understand something, to pay attention to the most important thing in a case, main in something, in an event, situation etc." In the headline "watch the roots" under analysis, grammar links are changed, destroying the set expression and changing the meaning of the utterance. Instead of the noun form root in its figurative meaning "beginning, source, foundation of something" (Contemporary Russian Dictionary 2001: 290), which is used only in singular, the article uses the plural form roots but with another meaning: "beginning of kinship, generation etc." (Sovremennyj tolkovyj slovar' russkogo yazyka 2001: 290). The sense of the headline is understood only after reading the first sentence of the article, which informs that, at the meeting of the State Council, one of the participants (the leader of the Liberal Democratic party of Russia) "acknowledged that the American laboratory claimed: his roots come from Einstein and Napoleon". The comic effect of the headline and its ironic potential are conditioned by the content of this false information and inadequacy of a personal discussion of relatives at the meeting devoted to important governmental problems.

(2) The textual subhead - "The State Council discussed the rural life and the ways from the plough to the Russian authorities". The text contains the set expression from the plough: it is usually used while characterizing "illiterate, uncultured man" (Sovremennyj tolkovyj slovar" russkogo yazyka 2001: 779). The noun authorities is used in the meaning of "political power, the right to rule the state or a region" (Sovremennyj tolkovyj slovar' russkogo yazyka 2001: 82). Thus, the set expression to authorities (entering the government, coming into power) means providing someone with the right to rule the state or a region. The ironic effect of the utterance ways from the plough to authorities is created due to an oxymoron (combination of incongruous notions in one semantic unity): "illiterate, uncultured man" cannot rule the state and solve important governmental problems.

\footnotetext{
${ }^{9} \mathrm{http} / / / \mathrm{kremlin} . \mathrm{ru} / \mathrm{structure} /$ state-council
} 
(3) An important ironic signal in contemporary media texts is the illustration and accompanying clarifications (in parentheses). There is such a signal in the text under analysis. There is an utterance above the photo of the meeting participants: "Participants of the State Council understood that they had to reconnect not only to the Russian President Vladimir Putin (when he would appear), but also to their ground and to their roots (which are yet to be found)".

In the context, the irony signal is expressed through the "cluster of highly sounding expressions" (reconnect to the Russian President, reconnect to their roots) and through the contrast expressed with the conjunction "not only - but": "they had to reconnect not only to the Russian President Vladimir Putin (when he would appear), but also to their ground and to their roots (which are yet to be found)".

The comic effect is also created due to the destruction of the set expression "reconnect to my roots" in the utterance "reconnect not only to the Russian President Vladimir Putin (when he would appear)". According to the dictionary materials, the verb reconnect has the following meaning in such a context: "High. Come close, lean, cuddle" (Dictionaries and encyclopedias on the Academic, 2020e).

The second ironic signal is in the final part of the utterance: "reconnect... to the ground and to their roots (which are yet to be found)". The phrase contains the hint at the fact that the participants of the State Council lost their roots long ago, i.e. their source, their people and their ground, or do not know their roots at all.

The mocking ironic tone of the headline grows into the main text of the publication - it is called to show the absence of results of such a meeting, the main event of which, as one of the participants said, "(...) is the fact of considering the problem of agriculture and the development of agricultural territories". According to the author's ironic statement, "we may now have rest with the sense of our duties fulfilled: we did a nice job".

Thus, the ironic signals, provoking the comic effect in contemporary ironic media texts, are diverse and correspond to the stylistic manner of the edition and are meant for the proved interaction with its reader.

\section{Possibilities of the linguistic description of ironic media text becoming the object of a court case}

The object of consideration in this section is the media text under the headline "Open letter to the Chairman of the Iskitim City Council (the abbreviation for the municipal council - a governmental organ in Russian cities) of deputies Fedotov Andrey Andreevich from the citizen of Iskitim Prosvetov Petr Nikolaevich", published in the journal Leader 2 (19) (April 2013). The interest to the study of this text is conditioned by the fact that, in 2013, this media text, created on the foundation of the ironic reconsideration of the reality, became the object of a court case: the lawsuit against the letter author over the defence of honour, dignity and business reputation was addressed by the subject whom the text was devoted to.

The author of the article made a linguistic study of the text for the court hearing. In this part of the paper, we shall try to answer the question which methods of research may be applied to the ironic text and if the ironic text may become an object of a court case.

\subsection{The open letter as an ironic media genre}

The text under consideration is written in the genre of an open letter which is a specific genre 
of public speeches in the press, widely spread in Russia since the end of the 20th century. In Tertychnyj's opinion, the common signs of the letter as the epistolary genre are the form of direct address of the author to the addressee (reader, listener) and the author's desire to encourage the addressee to urgent, active actions in connection with the subject of speech (Tertychnyj 2000).

The most effective tools of influence on the reader are the following: the ability "to express the most ingenious wriggles of the thought; to express any shades of feelings" (Tertychnyj 2000), which is necessary for achieving the understanding between the author and the reader; the presence of clearly defined "circle of addressees", the response of the reader, who is looking forward to a solution to the current issue discussed in the letter (Tertychnyj 2000). The letter itself may be considered as a public challenge to the addressee, "where he has to demonstrate publicly not only his professional skills or his power but his personal courage, intellect, moral firmness. (...) As a result, the invisible but clearly caught by the audience conflict situation may appear between the letter author and the addressee" (Tertychnyj 2000) which is finally interesting for readers.

Thus, the open letter, in its content, is an address to a person in power or a group of people with a demand, request, information or author's opinion on some socially important question, or an address to a wide audience with the purpose to draw public attention to a certain issue. Such publications are characterized by a brightly expressed personal character, emotionality or evaluation.

The text under analysis completely corresponds to the mentioned analytical genre:

- It is addressed by the author - retired Prosvetov Petr Nikolaevich (further on - the Author) - to a certain addressee - the official person, the chairman of the Iskitim city council (further on - the Addressee) and to some other city officials;

- The purpose of the author is to show the Addressee his real face through the creation of a comic image of the ex-deputy of the city council (further on - the Ex-deputy);

- To influence the Addressee and to draw the public attention, the Author chooses a special form of the letter - the ironic one, the purpose of which is to put the responsibility on the official (the Addressee) for a long and useless activity of the Ex-deputy, which was supported by him and other officials.

We believe that the open letter under analysis may be interpreted both as an attempt of the Author to establish dialogue with the authorities through the comic and as a public challenge to the Addressee, an invitation to the open "ring" where he must demonstrate his professional skills.

\subsection{Means and methods of linguistic analysis of conflict texts}

In stylistic relation, the text of the letter has a clearly expressed personal character ("want to share some ideas with you about the citizen of our city"), reflected in the stylistic form of the open letter, which uses various expressive means - such as rhetorical questions and exclamations: "He survived EVERYTHING! This is the reason for the Guinness book! And do you think this is the end? Not at all! EVERYBODY KNOWS HIM!"; the dialogue form of the expression: "And here I ask myself and you a question... Don't you think, respected Andrey Andreevich (...)"; as well as multiple repetitions, exclamations, epithets etc., adding an emotional, evaluative tone to the "Open letter", fulfilled with a special means of transmitting the material and characterized by scholars as the way of ironic reconsideration of the described. 
The stylistic analysis of ironic texts and their interpretation causes certain difficulties. As a rule, while analyzing such texts, the applied method of extracting logical-factual chains (Dridze 1976: 34-35), coming from the first, literate, meaning of the utterance, is of no use for studying the materials of "non-ironic" type. The reason for this is that the extracted chains may be qualified as evaluative but we cannot define the axiological direction of the information. For example, the following extracted phrase chains from the "Open letter" model the literal meaning and may seem quite a sincere, positive characteristic of the publication's hero (the Ex-deputy): " $a$ man with the capital letter; may set the example for all the men; noble, courageous and honest CITIZEN; a perfect ideal; constantly caring for the needs of his electors". These phrases, taken separately, are not marked as a "negative social evaluation of the person" - they present evaluative judgments of the author, which characterize the hero of the publication quite positively without the context.

The negative meaning of such utterances may be proved only with the support of the second textual level - leaning against the pragmatic meaning of the utterance and the whole text, based on semantic opposition, on the contrast which excludes the possibility of literal understanding of the phrase. To reveal the second (ironic) textual level, it is necessary to apply a complex semantic analysis aimed at finding the following interconnected and mutually conditioned "semantic aspects" (after Myrkin): reference of the content, which means "the correlation of the content and a certain subject of the reality, a certain situation"; modality of the content, understood as the evaluation (intellectual and emotional) of the announced fact; the background of the content (subtext or motivation of the utterance, not clearly defined in the phrase); and intention, "i.e. the target direction of the utterance" (Myrkin 1994: 47-48).

We think that the reference of the content in the text under analysis is formed due to enlisting some facts characterizing dishonest inclinations of the Ex-deputy, who: was brought to trial; transferred all his property to his wife in order to preserve the marriage and not lose the property acquired; combines his state service and commercial activity.

\subsection{Evaluation of means of creating the comic effect in the conflict text within complex linguistic analysis}

It is obvious that the background of the content (subtext or motivation of the utterance, not clearly defined in the phrase) (see Myrkin 1994: 47-48) is fulfilled through the ironic form of transmitting the material, due to which the negative facts of the person's activity are evaluated positively. The comic effect in this text appears due to the clash of two different textual levels (two world models): the first level is described with superficial textual structures, drawing an expressly positive image of the Ex-deputy; the second level expresses the author's attitude to the character and is formed with special language units containing irony signals, aimed at discrediting the character through mocking. The first level of the text describes the social values of the Ex-deputy and his company, the second level leans against a number of values, common and approved in the society (or some part of it), shared by the text's author, and mocks at what the society condemns.

The world model of the Ex-deputy (positive evaluation of his activity), as it was said before, is formed with the first, literate, meaning of the expression. The image of the Ex-deputy in the text is presented positively, and the author deliberately avoids ethical evaluation of his character's actions, letting the Addressee and readers evaluate them for themselves, for example:

The man, who in all his short life, did not offend a fly. When these silly people brought him to trial for debts, he was not embarrassed and, as a responsible husband and the head of the family, in spite of the fact that his spouse was ready to divorce him, could preserve the cell of our society (i.e. 
did not divorce his wife) and made the marital contract giving her the right ("the ownership of the house property") for the mutually acquired possession, to his life companion.

The comic effect, defining the modality of the message, is created due to the means of contrast, which actualizes the opposition "ours" / "theirs". In scholars' opinion, "the opposition of ours and theirs is considered in the categories of various links of a man" (Vinogradova 1995: 17) in this article, it is reasonable to speak of social links of the publication's "hero":

1) on the one hand, the image of the Ex-deputy contradicts the collective image of people who underestimated this man, i.e. "theirs", described expressly scornfully, for example: "some poor people dared to bring him to trial and - oh my God! - claimed the debts"; "When these silly people brought him to trial for debts"; "Pushy ("imprudent, inconsiderate"; Dictionaries and encyclopedias on the Academic, 2020f) creditors got nothing (...)"; "Paying attention to any denunciations (Colloquial. Tiny arguments, tiny intrigues, gossip; Dictionaries and encyclopedias on the Academic, 2020g) of envious people is disrespecting oneself' etc.;

2) on the other hand, the image of the Ex-deputy is associated with the representative of authorities ("ours" who defended him from enemies, for example: "Police, Prosecutors, Court, Justice Officers, general (...) and many others stood firmly for honor, dignity and business reputation of our hero. Who shall they together give a helping hand to?! You may write as much as you want - he is OURS, native. Blood from blood and flesh from flesh": "Colloquial. About kins"; flesh from flesh: "Bookish. About kin or ideological relations" (Dictionaries and encyclopedias on the Academic, 2020h).

The author of the text is a representative of the city community but he formally presents himself as "ours" (i.e. among those who are in power). Such a position may be considered as a special means which covers his disagreement and mockery under the "mask" of approval, which finally leads to mocking at the main character.

In the beginning of the text, there is a feeling that the author sincerely supports unrighteous actions of the Ex-deputy to protect his property: the text easily reads various emotions, which the author seemingly "feels", describing the vigorous activity of his "hero":

- $\quad$ athos, indignation and resentment - while describing the authority's actions towards the Ex-deputy, for example: "It is $O K$ that they try to malign him again ("to show in a bad way, to besmear"; Dictionaries and encyclopedias on the Academic, 2020i). They won't be able to";

- admiration and approval - while characterizing the actions of the Ex-deputy, for example: "He survived EVERYTHING!; he did not fail; he was not embarrassed and, as a responsible husband and the head of the family, in spite of the fact that his spouse was ready to divorce him, could preserve the cell of our society; This is indeed the example of sacrificial Russian man, warrior, marine, ex-deputy at last";

- false bewilderment why the other city dwellers underestimated the Ex-deputy's "merits": "And here I ask myself and you a question. What did we do in our life to reach him a little bit, this perfect ideal? And is there in our city Iskitim at least one man similar to him?"

To create the comic effect, the author uses the means of contrast in the text under analysis not only on the textual, but on subtextual level as well. 
It is interesting that, in one sentence, there may be a clash of (1) positive statements about the character and (2) mocking comments, expressing true emotions of the author towards the praised hero. Such a tool is used by the author addressing the Addressee of the letter (the chairman of the Iskitim city council) - this fragment finishes the description of the Ex-deputy's "victories" over those who tried to take away his property:

1) The comic effect of the following utterance is connected with modelling the effect of surprise: author's suggestion "making a record in the Guinness book" is perceived as absurd:

- 'Don't you think, dear Andrey Andreevich, that a man with such a strong, firm character, a justice protector, an example for all the male population should be honored in any way?";

- $\quad$ "And the best reward is still tiny compared to his merits. You simply must apply

to the Guinness book and support the image of our city Iskitim. There won't be any case like that!".

2) The mocking tone of the following utterance comes from the comment on how unimportant things the Ex-deputy did for citizens: (2) "(...) he organized New Year celebrations for our children" and a deliberately positive characteristic of this fact (1): "This is him, the ex-deputy of the City council, constantly caring for the needs of his electors (...), (2) "A man, who almost burnt at his deputy work, was the head of the deputy commission, took an active part in the solution of city problems. He organized New Year celebrations for our children".

This and similar fragments of the text are filled with author's mocking comments, the purpose of which is to persuade the readers that being a caring husband, a good military man (in the past), an educator of the growing generation, and a party member, the Ex-deputy did nothing good for Iskitim's citizens.

The text is rich with stylistic means, called to make the reader close to the author's intention and author's evaluation of the main character's actions.

The comic effect is also created with the means of hyperbolisation (using too many words), which helps to characterize both the present and the past of the Ex-deputy expressly positively: "Can you find many people who in spite of all the difficulties, sometimes at the expense of the family, sacrifice their life and health for other people?"; "What have we done in our life to come closer to this perfect ideal?; Isn't it the sacrificial example of the Russian man, a warrior... the ex-deputy at last. Isn't that a reason to make the record in the Guinness book!"; "He did everything right - it could not have been otherwise!" This tool creates the effect of satiety with the "positive" in the described image but the thought appears that the author is not sincere, i.e. there is an ironic subtext. The positive features of the character turn into neutral at the end of the text (for example, it informs that the Ex-deputy "during many years successfully combines his governmental service with the successful business activity" (which is forbidden by law), and mocking comments are becoming sharper: for instance, the author claims that the "hero" is supported by the authority representatives. [Ironically, the author notes: "(...) the authority and generals are not mistaken in people. That is why they are POWER".

Thus, the mechanism of creating the comic effect in the ironic media text aims at shifting the gradual friendly approach of the reader to the meaning intended by the author and his vision of "great friendliness" which the author describes his charter with. As Volkov states, the author gets him closer to the reader and, then, gradually stripping the sense of the written text, goes to open mockery (Volkov 1995). 
As follows from the conducted research, the text under analysis mentions the facts from the Ex-deputy's biography (see 4.2). It may be checked in the court if they correspond to reality and they may be refuted when they do not ${ }^{10}$. At the same time, the comic form of the content presentation in the ironic text cannot be the object for a court case because it is connected with evaluation and expression of the author's personal opinion (about the types of information in media texts see Belchikov, Gorbanevsky, Zharkov (2010: 137-142)).

\section{Conclusion}

The object of our description in the article is a contemporary media text, built with the means of ironic reconsideration of the social reality. The conducted analysis of the empiric material allows for drawing the conclusion about the demand of irony as a stylistic means of creating the comic effect and the semantic foundation of the text in contemporary Russian media texts. Irony helps the author to express his social position and forms the necessary image of a person or an event in the readers' consciousness. The study of comic-writing techniques in ironic media text allows to speak about their diversity. The basic mechanism for creating ironic texts consists in hiding the author's true feelings under the "mask" of positive evaluation of the actions and behaviour described in the text.

The basic means modelling the comic (ironic) subtext in contemporary Russian media texts is the means of contrast, fulfilled both on the textual and subtextual levels. The frequent means also include hyperbolization (too many words), leading to the effect of satiety with the "positive" in the described image and signalling about the presence of the hidden subtext, expressing the author's true intention.

Such socially active features of irony in media communication as critical attitude to the reality, social evaluation and brightly expressed emotional colour draw the attention of the audience. They can also give rise to speech conflicts in the area of media communications, which are brought before the courts. But close stylistic analysis of ironic media texts allows claiming that its factual component is tiny and expressed in the appropriate public form. The main objective of such texts is to express one's own vision of important social problems, to draw the public and governmental attention, and, probably, to show the solutions with the help of various stylistic means, containing irony signals, through mockery and deflation of personal image. As research on ironic media texts shows, the description of social and political reality through the comic is a discursive sign of journalistic and political discourse. As Sychev states, "the laughter communication claims the general human values of freedom, filled with the meanings of purification, rebirth, unity, optimism and contradicting the authoritative dogmas" (Sychev 2004: 4).

\section{Acknowledgements}

The author is sincerely grateful to the reviewers for constructive criticism and substantial remarks which helped to understand the problem under study deeper.

${ }^{10}$ According to Article 152 of the Civil Code of the Russian Federation, «The citizen has the right to demand in court the refutation of information defaming his honor, dignity or business reputation, if the person who disseminated such information does not prove that it is true» (http://www.consultant.ru/document/cons_doc_LAW_5142/1de6cd3cbb386056a2ecd2c64ff087b13c8de585/). 


\section{References}

Attardo, S. (2000). 'Irony as relevant inappropriateness'. Journal of Pragmatics 32 (6), pp. 793 826.

Belchikov, Yu. A. (et al.) (2010). Metodicheskie rekomendacii po voprosam lingvisticheskoj ekspertizy spornyh tekstov SM'I [Guidelines on the linguistic examination of controversial media texts]. Moscow: Informkniga.

Chepkina, E. V. (2000). Russkij zhurnalistskij diskurs: tekstoporozhdayushchie praktiki i kody (1995-2000) [Russian journalistic discourse: text-generating practices and codes (19952000)]. Yekaterinburg: Uralskij universitet.

Chernyshova, T. \& Klink, E. (2019). 'Applied Philology and Linguistic Expertise: Practical steps to extending discipline borders', in Oukhvanova, I. \& Senderska, J. (eds.), Discourse Linguistics and Beyond. Types of Discourse via Applied Research. Wydawnictwo Uniwersytetu Jana Kochanowskiego w Kielcach, 5, pp. 175-187.

Chernyshova, T. V. (2009). Teksty SMI v mental'no-yazykovom prostranstve sovremennoy Rossii [Media texts in the mental-linguistic space of modern Russia]. Moscow: URSS.

Chernyshova, T. V. (2014). 'Ironiya kak sotsial'naya otsenka' [Irony as a social assessment]. Stylistics today and tomorrow: conference proceedings. Moscow: Moscow State University, 1, pp. 236-242.

Demyankov, V. Z. (2003). 'Interpretatsiya politicheskogo diskursa v SMI' [Interpretation of political discourse in the media']. The language of the media as an object of interdisciplinary research. Moscow: Moscow University Press, pp. 116-133.

Dictionaries and Encyclopedias on the Academic, 2020a. [“маячить / loom, v."], Retrieved 2 December, 2020 from https://dic.academic.ru/dic.nsf/ogegova/104654

Dictionaries and Encyclopedias on the Academic, 2020b. [“играть с огнем / played with fire"]. Retrieved 2 December, 2020 from https://dic.academic.ru/dic.nsf/dic_synonims/250107

Dictionaries and Encyclopedias on the Academic, 2020c. [“давать по рукам / put through the hoop"]. Retrieved 2 December, 2020 from https://phraseology.academic.ru/2976

Dictionaries and Encyclopedias on the Academic, 2020d. [“зреть / watch, v."], Retrieved 2 December, 2020 from https://dic.academic.ru/dic.nsf/dic_synonims/250066

Dictionaries and Encyclopedias on the Academic, 2020e. [“припасть / reconnect, v."]. Retrieved 2 December, 2020 from https://dic.academic.ru/dic.nsf/ogegova/183646

Dictionaries and Encyclopedias on the Academic, 2020f. [“нахрапистый / pushy, adh.”]. Retrieved 2 December, 2020 from https://dic.academic.ru/dic.nsf/ogegova/120910

Dictionaries and Encyclopedias on the Academic, 2020g. [“кляуза / denunciations, n."]. Retrieved 2 December, 2020 from https://dic.academic.ru/dic.nsf/ogegova/84398

Dictionaries and Encyclopedias on the Academic, 2020h. [“"кровь от крови плоть от плоти / blood from blood and flesh from flesh"]. Retrieved 2 December, 2020 from https://phraseology.academic.ru/5829/; https://dic.academic.ru/dic.nsf/proverbs/36701/

Dictionaries and Encyclopedias on the Academic, 2020i. ["очернить / to malign, v."]. Retrieved 2 December, 2020 from https://dic.academic.ru/dic.nsf/es/124190

Dridze, T. M. (1976). 'Tekst kak ob"ekt smyslovogo vospriyatiya [Text as an object of semantic perception], in The semantic perception of a speech message (in conditions of mass communication). Moscow: Science, p. 34-45.

Duskaeva, L. R. (ed.) (2018). Medialingvistika $v$ terminah i ponyatiyah: slovar'-spravochnik [Medialinguistics in terms and concepts]. Moscow: FLINTA.

Duskayeva, L. R. (2019). 'Vektory praksiologicheskogo analiza v medialingvistike' [Vectors of praxeological analysis in medial linguistics]. Media Linguistics Journal 1 (6). Retrieved 20 
December, 2020 from https://medialing.ru/vektory-praksiologicheskogo-analiza-vmedialingvistike.

Dziemidok, B. (1974). O komicheskom [About the comic]. Moscow: PROGRESS.

Ermida, I. \& Chovanec, J. (2012). 'Humor, language and the media', in Ermida, I. \& Chovanec, J. (eds.), Language and Humour in the Media, Cambridge Scholars Publishing, pp. 1-8.

Ermida, I. \& Chovanec, J. (eds.) (2012). Language and Humour in the Media. Cambridge Scholars Publishing.

Klushina, N. I. (2008). Stilistika publicisticheskogo teksta [The style of journalistic text]. Moscow: MediaMir.

Kommersant. Retrieved 2 December, 2020 from https://www.kommersant.ru/doc/2457672

Kommersant. ru. Competitive Analysis, Marketing Mix and Traffic. Retrieved 2 December, 2020 from https://www.alexa.com/siteinfo/kommersant.ru

Kozhina, A. N. (ed.) (1987). Stilistika russkogo yazyka. Zhanrovo-kommunikativnyy aspekt stilistiki teksta [Stylistics of the Russian language. Genre-communicative aspect of the style of the text]. Moscow: Science.

Kozhina, M. N. (2014). Rechevedeniye. Teoriya funktsional'noy stilistiki [Speech. Theory of functional stylistics]. Moscow: Flinta.

Lazareva, M. E. (2005). Yazykovye sredstva vyrazheniya ironii na materiale norvezhskih publicisticheskih tekstov [Linguistic means of expressing irony on the material of Norwegian journalistic texts]. Abstract of the dissertation. Moscow: Moscow Linguistic University.

Medialingvistika [Media Linguistics Journal] 2 (6) (2019). Retrieved 2 December, 2020 from https://medialing.ru/vektory-praksiologicheskogo-analiza-v-medialingvistike/ Moscow's comsomolets [Moskovskiy komsomolets]. Retrieved 2 December, 2020 from https://www.mk.ru/daily/newspaper

Moskvin, V. P. (2006). Vyrazitel'nye sredstva sovremennoj russkoj rechi. Tropy i figury: Obshchaya $i$ chastnye klassifikacii. Terminologicheskij slovar [Expressive means of modern Russian speech. Trails and figures: General and private classifications]. Moscow: URSS.

Murzin, L. N. \& Stern, A. S. (1991). Tekst i yego vospriyatiye [The text and its perception]. Sverdlovsk: Publishing House of the Ural State University.

Myrkin, V. YA. (1994). Yazyk - rech' - kontekst - smysl. Arhangel'sk [Language - Speech Context-Meaning]. Arkhangelsk: Pomeranian International Pedagogical University.

Novaya filosofskaya entsiklopediya [New philosophical encyclopedia]. Retrieved 2 December, 2020

from

https://iphlib.ru/library/collection/newphilenc/document/HASH05148f47ad4907d1472a05

Odintsov, V. V. (2007). Stilistika teksta [Stylistics of the text]. Moscow: LCI.

Popova, T. I. (2017). 'Stilisticheskaya mnogosloynost' satiricheskogo politicheskogo kreolizovannogo teksta kak sredstvo sozdaniya ironii' [Stylistic layering of a satirical political creole text as a means of creating irony]. Media Linguistics Journal 4 (19), pp. 7 17.

Propp, V. Ya. (1999). Problemy komizma i smekha [The problems of comic and laughter]. Moscow: Labyrinth, Humer Library - Cultural Studies. Retrieved 2 December, 2020 from https://www.gumer.info/bibliotek_Buks/Culture/propp/02.php

Raskin, V. (1985). Semantic Mechanisms of Humor. Boston: D. Reidel.

Raskin, V. (2012). 'Humor and Hidden Theory', in Ermida, I. \& Chovanec, J. (eds.), Language and Humour in the Media, Cambridge Scholars Publishing, pp. 45-66. 
Shilikhina, K. M. (2014). Diskursivnaya praktika ironii: kognitivnyy, semanticheskiy, pragmaticheskiy aspekty [The discursive practice of irony: cognitive, semantic, pragmatic aspects]. Thesis of a doctor of Philology. Voronezh: Voronezh State University.

Shmeleva, T. V. (2007). 'Model' rechevogo zhanra' [Speech genre model], in Sedov K. F. (ed.), Anthology of speech genres: everyday communication. Moscow: Labyrinth, pp. 81-89.

Sovremennyj tolkovyj slovar' russkogo yazyka [Contemporary explanatory dictionary of the Russian language] (2001). St. Petersburg: NORINT.

Sychev, A. A. (2003). Priroda smekha, ili Filosofiya komicheskogo [The nature of laughter, or the philosophy of the comic]. Saransk: Publishing House Saransk. University.

Sychev, A. A. (2004). Smekh kak sotsiokul'turnyy fenomen [Laughter as a sociocultural phenomenon]. Thesis Doctor of Philosophy. Saransk: Mordovian State University named after N.P. Ogarev.

Tertychnyj, A. A. (2000). Zhanry periodicheskoj pechati [Genres of periodica]. Moscow: Aspekt Press. Retrieved 22 December, 2020 from http://evartist.narod.ru/text2/05.htm\#\%D0\%B7_19

Tsakona, V. \& Popa, D. E. (2011). 'Informal talk in formal settings: Humorous narratives in Greek parliamentary debates' in Tsakona, V. \& Popa, D. E. (eds.), Studies in Political Humour: In between Political Critique and Public Entertainment. Amsterdam \& Philadelphia: John Benjamins, pp. 61-81.

Tsakona, V. \& Popa, D. E. (2013). 'Confronting power with laughter'. European Journal of Humour Research, special issue on European political humour 1 (2), pp. 1-9.

Tsami, V. (2012). 'Language and Humour in the Media. Newcastle' in Chovanec, J. \& Ermida, I. (eds.), European Journal of Humour Research 1 (4), pp. 94-98.

Vinogradova, L. N. (1995). 'Helovek - ne chelovek v narodnykh predstavleniyakh' [A person is not a person in popular beliefs] in Man in the context of culture. Moscow: Slavic world, pp. 17-26.

Volkov, I. F. (1995). Teoriya literatury [Theory of literature]. Moscow: Prosveshchenie; Vlados. Retrieved 22 December, 2020 from https://studfiles.net/preview/3004064/

Weinrich, H. (1987). Lingvistika lzhi. Yazyk i modelirovanie social'nogo vzaimodejstviya [The Linguistics of Lying]. Moscow: Progress. Retrieved 22 December, 2020 from http://kursak.net/vajnrix-x-lingvistika-lzhi/

Weinrich, H. (2012). The Linguistics of Lying [transl. from Polish by Jane K. Brown \& Marshall Brown]. Washington: University of Washington Press.

Web Address Referencing [Accessed 2 December 2020]

https://www.mk.ru/press-center/

https://ria.ru/20091211/198562973.html

http://nvb.ru/firmy-novosibirska/lider_20.htm

https://www.mediaimpact.ru/press/moskovskij-komsomolets/799-moskovskij-

komsomolets

http://www.consultant.ru/document/cons_doc_LAW_5142/1de6cd3cbb386056a2ecd2c64

ff087b13c8de585/ 